\title{
Dating the Priestly teXt in the PRe-eXilic Period: Some REMARKS ABOUT ANACHRONISTIC SLIPS AND OTHER OBSTACLES
}

Author:

Esias E. Meyer ${ }^{1}$

\section{Affiliation:}

${ }^{1}$ Department of Old

Testament Studies,

University of Pretoria,

South Africa

\section{Correspondence to:}

Esias Meyer

email:

sias.meyer@up.ac.za

\section{Postal address:}

Department of Old

Testament Studies,

University of Pretoria,

Lynnwood Road, Pretoria

0002, South Africa

\section{Keywords:}

anachronistic slips;

Holiness Code; Kaufmann

School; Leviticus 26;

Priestly Text

\section{Dates:}

Received: 27 July 2010

Accepted: 15 Oct. 2010

Published: 24 Nov. 2010

How to cite this article: Meyer, E.E., 2010, 'Dating the Priestly text in the preexilic period: Some remarks about anachronistic slips and other obstacles', Verbum et Ecclesia 31(1), Art. \#423, 6 pages. DOI: $10.4102 /$ ve.v31i1.423

\section{This article is available} at: http://www.ve.org.za

(c) 2010. The Authors. Licensee: OpenJournals Publishing. This work is licensed under the Creative Commons Attribution License.

\section{ABSTRACT}

This article engages with the work of scholars such as Jacob Milgrom and Avi Hurvitz on dating the Priestly text $(\mathrm{P})$ in the pre-exilic period. In response to Wellhausen's argument that $\mathrm{P}$ is guilty of archaising, Milgrom and Hurvitz have always maintained that there would be some 'anachronistic slips'. In this article the author points out a few examples from Leviticus which could be understood as 'anachronistic slips'. The author also shows the difficulties one encounters when attempting to interpret a text such as Leviticus 26 in the pre-exilic period.

\section{INTRODUCTION}

Until about the middle of the 19th century scholars accepted that the Priestly text (P) was the basic document or the oldest stratum of the Pentateuch. ${ }^{1}$ This radically changed in the days of Edouard Reuss, Karl-Heinrich Graf, Abraham Kuenen and Julius Wellhausen. These scholars argued that P was later than Deuteronomy and in fact presupposes Deuteronomy and is thus an exilic or post-exilic document. ${ }^{2}$ This sequence became the standard view for most of the 20th century. Part and parcel of this view was also the value judgment that $P$ represented not only the last phase in the development of the Pentateuch, but also deterioration in the development of Israelite religion. As Collins (2004) puts it:

In Wellhausen's view, the Priestly theology reflected the decline of Israelite religion, from the spiritual heights of the prophets to the legalism of 'Late Judaism'.

(Collins 2004:173)

This was the most controversial part of Wellhausen's documentary theory, which drew immense criticism. ${ }^{3}$ In Wellhausen's view Israel's religion declined from what it was in the time of the prophets to the legalism of the Second Temple Period. Legalism has never been a comfortable word in Protestant circles and this clear prejudice in Wellhausen's work has also been extensively criticised by many other commentators as well, especially Jewish biblical scholars. Of these, Yehezkiel Kaufmann ${ }^{4}$ was the best example in the 20th century. Kaufmann defended the theological value of $\mathrm{P}$ and also dated it to a much earlier period, before the exile.

In this article I focus on this earlier dating of P. In most of the German-speaking academic world, but also in the rest of Old Testament scholarship, most scholars would still uphold Wellhausen's views on the dating of $\mathrm{P} .{ }^{5}$ The arguments for a pre-exilic dating of $\mathrm{P}$ have been mostly based on the development of the Hebrew language. Kaufmann's multi-volume work is the best example of this, but following in his footsteps many other Jewish scholars have argued similarly. ${ }^{6}$ These include scholars such as Avi Hurvitz, Menaham Haran and more recently Israel Knohl and Jacob Milgrom. In this article I will especially engage with the work of Jacob Milgrom, who wrote what is probably the best and most extensive commentary on Leviticus, ${ }^{7}$ but who (following Kaufmann and others) dates both P and the Holiness Code $(\mathrm{H})$ in the pre-exilic period. The work of Avi Hurvitz will also feature and to a much lesser extent the work of Knohl. But before we go there, we need to mention some of the other important issues in interpreting $\mathrm{P}$.

Regarding the characteristics of P scholars are mostly in agreement. Zenger (2004:157-159) identifies features such as a fondness for stereotypical formulas and repetitions, a fondness for elements which convey a certain order in the world, an interest in cultic and ritualistic phenomena, et cetera. ${ }^{8}$ There is also very little debate about where P starts; P starts with the first creation story in Genesis 1 and is found throughout Genesis and Exodus 1-24 as a kind of editorial strand (or for some, a proper source; see below) which links narratives together. The core of P (according to Collins 2004:139) is found from Exodus 25 onwards through Leviticus up to Numbers 10 and these texts are mostly legal in character.

\footnotetext{
1.See, for instance, Collins (2004:49) or Blenkinsopp (1992:7-8) or Zenger (2004a:90), who discusses the work of scholars such as Johann Gottfried Eichhorn, Carl David Ilgen and Hermann Hupfeld.

2.See, for instance, Zenger (2004a:90-91), or Blenkinsopp (1992:4-11).

3.Blenkinsopp (1992:12) is of the opinion that this negativity towards rituals was not only the result of 'the prevalence of anti-Semitism in academic circles', but he argues that towards the end of the Prolegomena it becomes clear 'that his animus is directed more at the propensity of religious institutions in general to stifle the free and spontaneous expressions of the human spirit'.

4.Kaufmann's main work appeared between 1937 and 1956 in Hebrew and was published in English in an abbreviated version translated by M. Greenberg 'The religion of Israel from its Beginnings to the Babylonian Exile', New York, Schocken, 1972. This article does not engage with his work directly, but with scholars (especially Milgrom and Hurvitz) who have followed in his footsteps.

5.It would be fairly safe to say that the contribution of Kaufmann has not been taken seriously in the German-speaking academic world. Zenger (2004b:166) only mentions the debate with the Kaufmann School in a paragraph with hardly six lines. He concludes (Zenger 2004b:166): 'Dass freilich die hier zur Debatte stehende "Priestergrundschrift" vorexilisch sein kann, ist wenig wahrscheinlich'. The only exception (which I know of) is the work of Krapf (1992), which engages seriously with the contribution of Yehezkiel Kaufmann.

6.See Blenkinsopp's (1996:495-518) extensive critical engagement with the work of Kaufmann, but see also the response to this from Milgrom (1999) and Hurvitz (2000).

7.See Milgrom (1991, 2002, 2001).

8.See also Gerstenberger (2005:134-135), or Ska (2006:146), who also says that P has always been 'relatively easy to identify'.
} 
There is actually much more debate about where $\mathrm{P}$ ends (Gerstenberger 2005:134). Is it Deuteronomy 34:7-9, Exodus 40, Leviticus 9, Numbers 27, or Joshua 18:1? ${ }^{9}$ What is important is that most of the book of Leviticus is usually regarded as part of $P^{10}$, although Leviticus $17-26$ is viewed as a fairly distinct part, but we will return to that later.

Other aspects of Wellhausen's original views have been questioned. For instance, for Wellhausen $\mathrm{P}$ was originally an independent narrative that was later combined with other independent narratives (such as the Yahwist and the Elohist). Towards the end of the 20th century this view has been questioned by many scholars, who have argued:

... that $P^{G}$ never was an independent narrative, and that the material assigned to it is best explained as deriving from an editor who reworked the older sources incorporating a mass of additional material, some from sources which he inherited and some composed by himself.

(Nicholson 1998:197)

In this view the Priestly authors are still usually regarded as those who had the last say in the editing of the Pentateuch, which does not change the dating of $P$ much, but simply changes its character from being an independent narrative to being an editorial layer, albeit a very extensive one.

Another issue has also been the relationship between the Holiness Code (Lv 17-26) and P. When Klostermann (1893:385) coined the term 'Holiness Code', it was regarded at that stage by some scholars (e.g. Horst 1881) as referring to the work of the prophet Ezekiel, but Klostermann actually argued against this view. For many years afterwards the Holiness Code $(\mathrm{H})$ was regarded as an older collection of laws which was at some stage incorporated into P. Lately (especially after Elliger 1966 and Cholewinski 1976) many scholars have argued that $\mathrm{H}$ is later than $\mathrm{P}$ simply because $\mathrm{H}$ seems to know of $\mathrm{P}$ and other earlier texts, or as Collins (2004) puts it:

Most importantly, these chapters attempt to integrate ethical commandments of the type found in the Decalogue, and emphasized in Deuteronomy and the Prophets, with the more specific cultic and ritual laws of the Priestly tradition. ${ }^{11}$

(Collins 2004:148)

$\mathrm{H}$ is thus broadly speaking in the same tradition as $\mathrm{P}$ and would be treated as part of $\mathrm{P}$ by most textbooks. Yet $\mathrm{H}$ is also dated later than the rest of $\mathrm{P}$. This view is shared by many German scholars (e.g. Otto 1999; Grünwaldt 1999) who date both P and $\mathrm{H}$ in the post-exilic period, as well as by Jewish scholars such as Knohl (1995) and Milgrom (1991, 1999), who date both in the pre-exilic period..$^{12}$ However, let us turn to Milgrom and consider how he justifies dating $\mathrm{P}($ and $\mathrm{H})$ in the pre-exilic period. 9.For excellent overviews of these issues see Ska (2006:147-151) and Zenger
(2004b:164-166). For a monograph on the subject see Frevel (2000).

10.One should also keep in mind that German scholars have from the start (i.e. Wellhausen) distinguished between $\mathrm{P}^{\mathrm{G}}$ ('G' for German 'Grundschrift') and PS ('S' for supplement), which represent two different layers in P. Zenger (2004b:159) points out that this distinction is widely accepted amongst (German) scholars, but scholars differ on the extent of each of these layers. For some, $P^{G}$ consisted mostly of narratives, which were later supplemented with legal and ritual texts, and these are called $P^{S}$. Others differ. With regard to the debate about the end of $P$, this debate actually refers to the end of the original $P^{G}$. Thus some scholars who argue for an end in Exodus 40 or Leviticus 9 would still consider the rest of Leviticus and Numbers as part of $P$, but then the second layer of $P$, namely $P$ s.

11.Eckart Otto (1999:134), a renowned German scholar on the Pentateuch, puts similarly: 'Wichtig ist die Einsicht, daß in Lev 17-26 mit priesterlicher Terminologie gegen die Priesterschrift polemisiert wird im Dienste einer Intergration des Deuteronomiums in die Priesterschrift, um andererseits aber auch Korrekturen am deuteronomischen Reformprogramm, insbesonder in Lev 17 und 25, vorzunehmen:

12. These Jewish scholars would agree that $\mathrm{H}$ is later than $\mathrm{P}$, but would not agree that $\mathrm{H}$ might also be later than Deuteronomy. Milgrom and Knohl regard Deuteronomy as later than $\mathrm{P}$ and $\mathrm{H}$.

\section{A PRE-EXILIC DATING OF P AND H AND ANACHRONISTIC SLIPS}

Jacob Milgrom ${ }^{13}$ dates $\mathrm{P}$ and $\mathrm{H}$ in the time of Hezekiah and his arguments are mostly based on the development of biblical Hebrew. His arguments focus on semantics and how the meanings of words changed over time. Milgrom (1991:3-13) would argue that many key terms used in $\mathrm{P}$ are either not used in other post-exilic literature or have changed their meaning. Using the work of Avi Hurvitz,$^{14}$ he lists many words typical of $\mathrm{P}$ which are replaced by synonyms in Ezekiel and other postexilic texts such as Chronicles. An example of this is the fact that, according to Milgrom (1991:5), ${ }^{15}$ the Priestly word for assembly is 'edah which we find throughout Leviticus in both $\mathrm{P}$ and $\mathrm{H}$ $(4: 13,15 ; 8: 3,4,5 ; 9: 5,10: 6,17 ; 16: 5 ; 19: 2 ; 24: 14,16)$. In post-exilic literature this apparently changes to qahal (e.g. Ezr 10:2; Neh 8:2 and 2 Chr 23:1-3). According to Milgrom (1991:5) the term 'edah 'is no longer attested after the ninth century' and is thus for Milgrom a pre-exilic word which points to the alleged pre-exilic date of $\mathrm{P}$ and $\mathrm{H}$

Scholars arguing for a post-exilic date would usually not be too impressed with this argument because Wellhausen acknowledged from the start that $\mathrm{P}$ was guilty of archaising, thus writing after the exile but writing in the idiom of many centuries before. According to Collins (2004):

All of this shows that the language of $P$ was not invented in the exilic or postexilic period. But Priestly, liturgical language is often archaic, and terminology is often preserved in ritual contexts long after it has fallen out of use in popular speech.

(Collins 2004:175)

Milgrom's (1991:7) response to this kind of criticism is that, if $\mathrm{P}$ were attempting to use older language, would it not be likely that in such an extensive corpus $\mathrm{P}$ would betray itself by means of 'some anachronistic slip'? Milgrom is following Hurvitz (1982:163), who also argued against the alleged archaising tendency in $\mathrm{P}$ by stating that one would only be able to use this argument if 'one can furnish positive evidence proving the existence of late linguistic elements in the same work'. Both Milgrom and Hurvitz would thus acknowledge that a text is late, while attempting to sound old, if there is linguistic evidence in the sense of a late word slipping into the older-sounding text; this is what Milgrom refers to as an 'anachronistic slip'.

In engaging with Blenkinsopp's (1996) criticism of the Kaufmann School, Hurvitz (2000) has recently attempted to get some methodological clarity on this issue. Hurvitz (2000:185) argues that all languages change over time and that this is a 'continuous and gradual historical process'. Hurvitz (2000) understands this process as follows:

Indeed, in many cases we witness an age of transition, in which the emerging elements make their first appearance while, concurrently, their old counterparts do not promptly abandon the field in the face of the advancing new-comers. Under these circumstances we may well observe a struggle between the competing parties, at the end of which the winner completely displaces his rival(s). In other cases, however, the differing elements manage to exist peacefully side by side. Sometimes they simply turn into stylistically synonymous expressions; sometimes each assumes a distinct sense, or shade of meaning, following a process of semantic differentiation.

(Hurvitz 2000:185)

We are therefore faced with two scenarios. In the first instance new elements eventually replace older elements. The second possibility is for the old and the new to find a way of living

13.See, for instance, Milgrom's (1991, 2000, 2001) commentary on Leviticus, but see especially Milgrom (1999), where he responds to Blenkinsopp's (1996) criticism of the Kaufmann School.

14.Milgrom relies extensively on Hurvitz (1982)

15. Here Milgrom is using an older work by Hurvitz (1971-1972) as his source, one to which I did not have access and which is in Hebrew. 
together, either as synonyms or by eventually ending up with different meanings. Regarding biblical Hebrew, Hurvitz (2000) writes as follows:

Be that as it may, the basic fact remain that - as far as the late sources are concerned - both the old (= Classical) and the new (= Post-Classical) elements often co-exist and they function on the linguistic and/or literary scene simultaneously; they are not mutually exclusive.

(Hurvitz 2000:186)

Hurvitz (2000:186) then refers to the book of Esther which, according to him, is a good example of the writing of 'a master of Classical Hebrew style', but with plenty of neologisms and loanwords from the Persian period. Hurvitz (2000:187) takes issue with Blenkinsopp (1996), who (according to him) does not understand this principle. Blenkinsopp (1996) previously argued that in order for $\mathrm{P}$ to be pre-exilic the following should be shown:

... (a) a term used consistently in $P$ is never used in texts known to be post-exilic with the exception of those clearly and directly dependent on $P ; \ldots$

(Blenkinsopp 1996:514)

Thus Blenkinsopp's argument would boil down to the following regarding 'late' qahal and 'early' 'edah; the 'early' term 'edah (which is found fairly frequently in $\mathrm{P}$ and $\mathrm{H}$ ) would have to be completely absent in post-exilic texts. Only then would it be possible to argue that $P$ is pre-exilic. Hurvitz (2000:186-187) does not agree with this, because this scenario is clearly possible within the development of a language where older and newer elements exist together. He concludes by saying that:

The occurrence of any lexeme, Priestly or non-Priestly, in 'texts known to be post-exilic' tells us nothing - if taken in isolation about the lateness or earliness of that lexeme.

(Hurvitz 2000:188)

As an example of this, Milgrom (1991:5) argued (following Hurvitz) that 'edah 'is no longer attested after the ninth century'. A quick concordance search with any standard Bible program would indicate that the term does actually occur in a postexilic text. It appears in 2 Chronicles 5:6. ${ }^{16}$ If we take Hurvitz's argument seriously (and if we disagree with Blenkinsopp), it would not say much if we find an older word in a later text. According to Hurvitz, this is often the case in any language and it does not mean that those texts from Leviticus are post-exilic. ${ }^{17}$ In this sense it seems that Hurvitz's criticism was fair.

The question then becomes what the implications would be of finding a so-called later word in a text which is presumably early. Do we find examples of later terms occurring in allegedly older texts such as Leviticus? That is, do we find examples of those anachronistic slips that Milgrom was looking for?

I think we do and the 'late' qahal is a good example. It actually occurs five times in Leviticus (4:13, 14, 21, 16:17 and 33). In Leviticus 4:13 we find both terms in the same verse ${ }^{18}$ :

If the whole congregation ('edah) of Israel errs unintentionally and the matter escapes the notice of the assembly (qahal), and they do any one of the things that by the LORD's commandments ought not to be done and incur guilt; ...

The two terms seem to have a similar meaning. In verse 14 the 'late' qahal is used again and verse 15 falls back on the 'early' 'edah, which really leaves the impression that they are used interchangeably and as synonyms. This is thus another example of old and new terms being mixed together, but it is different

16. The New Revised Standard Version translates 'edah with 'congregation' in 2 Chronicles 5:6: 'King Solomon and all the congregation of Israel, who had assembled before him, were before the ark, sacrificing so many sheep and oxen that they could not be numbered or counted.'

17.Against Milgrom and Hurvitz one could refer to Levine (2003:19), who has pointed out that 'edah 'is attested in the Elephantine Aramaic papyri of the fifth century BCE'. We thus have extra-biblical evidence of the late usage of 'edah.

18. All biblical quotes are from the New Revised Standard Version. from the example in 2 Chronicles 5:6. The latter was an example of a late text with a mixture of late and allegedly early terms. Hurvitz is right that in itself that does not mean anything. Yet now (Lv 4:13) we have a text which is supposedly old with later terms mixed in. Later terms in an earlier text can only be described as anachronistic. One could say that this is an excellent example of an author trying to use older Hebrew with a much later term slipping in. ${ }^{19}$

In Milgrom's (1991:242-243) commentary on Leviticus 4:13 he acknowledges that both terms occur in the same text and asks whether this is done for 'literary' reasons. He then repeats Hurvitz's argument that 'edah does not occur in writings after the end of the monarchy (which we saw above is not exactly true, i.e. 2 Chr 5:6) and that 'edah is thus an early term. He also argues again that qahal is the term that was used in post-exilic literature and then concludes (Milgrom 1991):

Thus it can be suggested that once edah fell into desuetude, subsequent redactors of $P$ had no choice but to substitute qahal for it, the very word that has usurped its place. Out of reverence for the text, however, they did not replace every 'edah but only once or twice in each pericope, so that the reader would know that the term he knew as qahal originally read 'edah. Thus the alternation of'edah and qahal in legal material may be due to editorial activity rather than stylistic criteria.

(Milgrom 1991:243)

Milgrom thus acknowledges that we have both the late and the early terms in the same verse, but for him this is not a case of an anachronistic slip-up, but rather the tracks left behind by a later editor. He does not mention who these later editors were and when they did their editing. It thus seems rather unsatisfactory that a possible example of an anachronistic slip is blamed on a later editor. However, another possible anachronistic slip has been pointed out recently.

In a Festschrift for Baruch Levine (who as Jewish scholar has argued for a post-exilic dating of $\mathrm{P})^{20}$ Sperling (2003) has pointed to a further anachronistic feature of $\mathrm{P}$, the word for trousers (miknasim). We find this word only five times in the Hebrew Bible, of which four are in P, namely Exodus 28:42 and 39:28 and Leviticus 6:3 and 16:4. The fifth example is found is Ezekiel 44:18. The question then becomes when people started to wear 'trousers' in the Ancient Near East. According to Sperling (2003), the evidence points to the fact that the Persians started this trend with their culture's respect for good horsemanship. Sperling (2003) comes to the conclusion:

The implications of trousers for dating the final form of the Priestly source are obvious. No biblical writer would have seen Iranian garb before the 6th century B.C.E. The occurrence of an Iranian article of clothing in Hebrew texts leads to the inescapable conclusion that the Hebrew texts in question must be no earlier than the 6 th century B.C.E.

(Sperling 2003:380-381)

If Sperling is correct, then in Milgrom's words this is a major 'anachronistic slip'. If $\mathrm{P}$ is pretending to be writing archaic Hebrew and then portrays their priests on the altar in the desert in Persian clothing, it is indeed a dead giveaway that they are writing in a much later period than they pretend.

These are just a few examples and, in all fairness, this is just the tip of the iceberg. Proponents of a pre-exilic dating for $\mathrm{P}$ have amassed a mountain of linguistic arguments in favour of their dating. Yet time will probably tell that such arguments are not foolproof, as I have just shown with regard to 'edah and qahal and with Sperling's argument which caught the priestly authors 'with their pants down'. Regarding 'edah and qahal, it also sounds rather unconvincing when Milgrom has to resort to a blame-it-on-the-editor argument when he finds both 'old' and 'new' terms in Leviticus 4:13.

19.That is, if one accepts that 'edah is early, which would mean that the author of the Elephantine Aramaic papyri was also archaising.

20.See Levine (2003) referred to above and especially Levine's (1989) commentary on Leviticus. 
In the rest of the article I argue that there are other texts in $\mathrm{H}$, which I find very difficult to imagine having a pre-exilic date. One such text is Leviticus 26, to which I will now turn.

\section{LEVITICUS 26 AND THE EXILE}

Leviticus 26 is generally regarded as an initial conclusion to the Holiness Code $(\mathrm{H})$, with chapter 27 being added sometime later. ${ }^{21}$ Chapter 26 starts with two apodictic verses very much reminiscent of the Decalogue and the rest of the chapter can be divided into two parts, namely blessings (vv. 3-13) and curses (vv. 14-45). In the first part YHWH promises Israel that they will live happily ever after if they were to keep his commandments. Verses 5 and 6 describe a land that is flourishing and providing more than enough food for its inhabitants and a land which is peaceful:

Your threshing shall overtake the vintage, and the vintage shall overtake the sowing; you shall eat your bread to the full, and live securely in your land. (Lv 26:5)

And I will grant peace in the land, and you shall lie down, and no one shall make you afraid; I will remove dangerous animals from the land, and no sword shall go through your land. (Lv 26:6)

Furthermore YHWH will live and walk amongst his people. This part is concluded in verse 13 with YHWH reminding the addressees that he had delivered them from Egypt and that he had broken their yoke with the result that they can walk erect. The rest of the chapter is mostly rather dark and dreadful and only changes towards the end of chapter 26 . This is where we find curses which spell out what will happen to the addressees if they do not keep the commandments. One of the chief results will be that they will lose their land. The sustaining land of verses 5 and 6 changes into a barren land, as verse 20 states: 'Your strength shall be spent to no purpose: your land shall not yield its produce, and the trees of the land shall not yield their fruit'.

Verse 33 states it even more aptly: 'And you I will scatter among the nations, and I will unsheathe the sword against you; your land shall be a desolation, and your cities a waste'.

The land is further presented as empty and enjoying its Sabbaths, while the addressees are in the land of their enemies. The land is having its rest which it never had when the addressees lived there (verses $34-35$ ). Things only change from verse 40 onwards, where it is said that if the addressees were to confess their iniquities, then $\mathrm{YHWH}$ in his turn would remember his covenant with Abraham, Isaac and Jacob (verse 42). This remembering by YHWH will open up new possibilities and, although a return to the land is never mentioned, the possibility at least is implied by the fact that $\mathrm{YHWH}$ also remembers the land lying empty (also verse 43). Scholars who date $\mathrm{P}$ and $\mathrm{H}$ in the post-exilic period usually understand Leviticus 26 as a text which already witnesses to the experience of the Exile. Thus Levine (2003) would say:

It reflects the progressive, ever deepening despair of the Judeans in the Babylonian exile, but ends with the divine promise that the God of Israel will remember his covenant with the Patriarchs, and remember the desolate land, as well.

(Levine 2003:22)

This text seems to be one of the biggest problems for those arguing for a pre-exilic date simply because it exudes an awareness of exile. One proponent of the pre-exilic date, Israel Knohl (1995:205), acknowledges that the curses in Leviticus 26 reflect 'the impact of forced mass exile on the people'. However, because he dates $\mathrm{H}$ to the period of Ahaz and Hezekiah, he argues that it refers to the exile of Israel to Assyria. This is difficult to 'prove' or 'disprove', but seeing as nobody ever came back from that exile (that we know of), why then the positive

21. The main reason for this argument is that $27: 34$ basically repeats what was already concluded in 26:46. See, for instance, Otto (1999:181) and Grünwaldt (1999:128) Bertholet (1901:97) already put it well when he said more than a hundred years ago that Leviticus 27 'will nach v 34 auch noch zu den Befehlen am Sinai gehören, kommt aber freilich hinter 26:46 nach Thorenschluss'. ending where $\mathrm{YHWH}$ remembers his covenant and the land? Similarly to Knohl, Milgrom (2001) argues that:

Even if we admit that the appendix to Lev 26 had doom (i.e. exile) in mind, need it be the Babylonian Exile? It could just as well have been referring to the exile of North Israel in the eighth century (see below). Alternatively, it could even have in mind the exile of Judeans in 701 B.C.E. Despite the silence of such an exile throughout the Bible, particularly in the book of Kings, ...

(Milgrom 2001:2363)

Milgrom (2001:2363) is thus not only arguing that these texts of doom could be referring to some earlier exile, but he also regards them as an 'appendix' to Leviticus 26; he (Milgrom 2001:2365) thinks that there are two layers in Leviticus 26 . The first layer consists of verses $3-33 a, 36-42$ and 45 and the appendix or second layer consists of verses $33 \mathrm{~b}-35$ and $43-44$.

These texts share what Milgrom (2001:2365) calls the 'sabbatical theme' and these might for him refer to the Babylonian exile (although he leaves the possibility open that it might be the Assyrian exile or a reference to 701 B.C.E. as we saw above). Verse 33 reads: 'And you I will scatter among the nations, and I will unsheathe the sword against you; your land shall be a desolation, and your cities a waste.'

According to Milgrom (2003:2322-2323), the second part of the verse (i.e. your land shall be a desolation, and your cities a waste) is redundant, because it repeats what has already been said in verses 31a and 32a. In the first part of verse 33, the text has already moved to the exile with the addressees scattered amongst the nations, but now the second part of the verse moves back to the issue of land. Therefore along with verses 34 and 35, which also refer to the land and to the Sabbath, it should be regarded as a later interpolation. In Milgrom's (2001:2325) understanding verse 33 a continues only in verse 36 , where the text returns to the plight of the people. Thus Milgrom expects of the text to say something of the desolation of the land and then to move on to the exiles and not mention the land again. It is not clear why he expects this of the text. Could this not be regarded as some kind of artistic juxtaposing going on? As the text is now, it shifts the focus from exile to desolate land and then back to exile and desolate land again. Could one not simply argue that this is good writing? Why does the movement back to the desolate land have to be a later addition?

Regarding verses 43 and 44, Milgrom (2001:2337) adds a grammatical argument that the perfects (i.e. verbs) in these verses 'betray the exilic provenance for the composition of vv. 43-44'. This argument is not very convincing, since we find plenty of other perfects in Leviticus $26^{22}$ and not only in those texts which are supposedly later additions. Still, I suppose one could argue that verses 36-42 focused on the survivors in the land of their enemies and again in verse 43 there is a movement back to the land, but the same questions asked above apply here as well. Is this not simply a good way of writing? In verse $42 \mathrm{YHWH}$ not only remembers the covenant, but also the land towards the end of the verse. Is this not an ideal place for the author to move back to the issue of land?

Klaus Grünwaldt (1999:120)23 has seen another pattern in verses 39-45 which makes him want to view this as one unit. Grünwaldt (1999:120) identifies a scheme of 'Trostlosigkeit' and 'Hoffnung' in these verses and the text swings like a pendulum between the two. The text starts with a 'hopeless' verse, which is always followed by a 'hopeful' verse, which Grünwaldt presents 2.Large parts of Leviticus 26 consist of waw consecutive + perfect chains often following an imperfect. See Meyer (2005:162), who argues that the largest part of vv.3-33 'could on formal grounds be described as being part of either the protasis or the apodosis of a conditional sentence dominated by wc. + perfect chains'. See also Steymann (1999:274-284), who describes these chains in further detail.

23.I am aware of the irony of my using Grünwaldt (1999) to argue that there are no layers in a text. Like many Germans before him, Grünwald (1999.23-130) still attempts proper Literarkritik and his objective is to identify the 'Ursprüngliche
Gestalt' of $\mathrm{H}$. He is much more modest than many of his German predecessors and is adamant the only criteria that he (Grünwaldt 1999:23) will use are 'Widersprüche, unvereinbare Spannungen' and 'störende Doppelungen'. For a summary of all the 'additions' identified by means of these criteria, see Grünwaldt (1999:130). Regarding Leviticus 26 , he considers only verse 46 as a later addition. 
as follows (1999:120):

$\begin{array}{ll}\text { A V.39 } & \text { A }^{\prime} \text { V.40 } \\ \text { B V.41 } & \text { B }^{\prime} \text { V.42 } \\ \text { C V.43 } & \text { C }^{\prime} \text { V.44-45 }\end{array}$

Thus verse 39 tells us about the people suffering because of their sins, but then in verse 40 we hear of the people repenting. Verse 41 again describes what YHWH did to them and in the next verse we have YHWH remembering his covenant. Verse 43 returns to the empty land and verse 44 promises that $\mathrm{YHWH}$ will not reject the people. Thus even if verses $43-44$ move from the issue of the exiles to the issue of land, they still follow the same pattern as the previous verses.

I thus find it rather unconvincing that Milgrom would revert to identifying a second layer in order to support his dating of the text. If you regard the whole text as post-exilic, then this kind of surgery would not be needed.

\section{CONCLUSION}

It should be said again that Milgrom and other adherents of the Kaufmann School offer much more than these few observations made above. It is unfortunate that their arguments have not been taken seriously (especially in the German-speaking world). In this article, I have attempted to point out that some aspects of their arguments are not entirely convincing.

One cannot help but feel that the origins of these debates do not lie simply in the fact that Wellhausen dated $\mathrm{P}$ in the postexilic period, but had more to do with the fact that he attributed very little theological value to $P$. Wellhausen was clearly wrong and many scholars who agree with his dating of the text would strongly disagree with his theological assessment of P. Some scholars have already started to rectify this negative value judgment of $\mathrm{P}$, but there is still much room for improvement and biblical scholars will in future need to take priestly theology and the priestly world view much more seriously.

One of the best efforts to describe the theological value of $\mathrm{P}$ has been the work of Daniel Smith-Christopher (especially 2002). His sociological description of the trauma of exile has helped us to understand priestly theology better and its attempt to police the boundaries and to protect the identity of their community. If we date these texts to before the exile, then we have to start from scratch to understand the priestly worldview better.

Although the Kaufmann School should be considered as presenting a serious challenge to the majority view of dating $\mathrm{P}$ in the post-exilic period, it seems clear from the evidence why this is still the majority view.

\section{REFERENCES}

Blenkinsopp, J., 1992, The Pentateuch. An Introduction to the First Five Books of the Bible, Yale University Press, New Haven.

Blenkinsopp, J., 1996, 'An Assessment of the Alleged PreExilic Date of the Priestly Material in the Pentateuch', Zeitschrift für die Alttestamentliche Wissenschaft 108, 495-518.

Cholewinski, A., 1976, Heiligkeitsgesetz und Deuteronomium. Eine vergleichende Studie [The holiness code and Deuteronomy. A comparative study], Biblical Institute Press, Rome.

Collins, J.J., 2004, Introduction to the Hebrew Bible. With CD-Rom, Fortress Press, Minneapolis.

Elliger, K., 1966, Leviticus, Mohr, Tübingen.
Frevel, C., 2000, Mit Blick auf das Land die Schöpfung erinnern. Zum Ende der Priestergrundschrift [The land in order to remember creation. With regard to the end of the Priestly source.], Herder, Freiburg.

Gerstenberger, E.S., 2005, Israel in der Perserzeit. 5. und 4. Jahrhundert v. Chr [Isreal in the Persian period. 5 and 4 B.C.], Kohlhammer, Stuttgart.

Grünwaldt, K., 1999, Das Heiligkeitsgesetz Leviticus 17-26. Ursprüngliche Gestalt, Tradition und Theologie [The Holiness Code of Leviticus 17-26. Original form, tradition and theology], Walter de Gruyter, Berlin.

Horst, L., 1881, Leviticus XVII-XXVI und Hezekiel. Ein Beitrag zur Pentateuchkritik [Leviticus XVII-XXVI and Ezekiel. A contribution to the study of the Pentateuch], Eugen Barth, Colmar.

Hurvitz, A., 1971-1972, 'On the Priestly Term 'edâ in the Bible', Tarbiz 40, 261-267. (Hebrew)

Hurvitz, A., 1982, A Linguistic Study of the Relationship between the Priestly Source and the Book of Ezekiel. A New Approach to an Old Problem, J. Gabalda et Cie, Paris.

Hurvitz, A., 2000, 'Once Again: The Linguistic Profile of the Priestly Material in the Pentateuch and its Historical Age. A Response to J. Blenkinsopp', Zeitschrift für die Alttestamentliche Wissenschaft 112, 180-191.

Klosterman, A., 1893, Der Pentateuch. Beiträge zu seinem Verständnis und seiner Entstehungsgeschichte [The Pentateuch. Contributions to its understanding and its history], Deichert, Leipzig.

Knohl, I., 1995, The Sanctuary of Silence, Fortress Press, Minneapolis.

Krapf, T.M., 1992, Die Priesterschrift und die vorexilische Zeit. Yehezkel Kaufmanns vernachlässigter Beitrag zur Geschichte der biblischen Religion [The Priestly source and the pre-exilic Period. Yehezkel Kaufmann's neglected contribution to the history of biblical religion], Vandenhoeck \& Ruprecht, Göttingen.

Levine, B.A., 1989, The JPS Torah Commentary. Leviticus, Jewish Publication Society, New York.

Levine, B.A., 2003, 'Leviticus: Its Literary History and Location in Biblical Literature' in R. Rendtorff \& R.A. Kugler (eds.), The Book of Leviticus. Composition and Reception, pp. 11-23, Brill, Leiden.

Meyer, E.E., 2005, The Jubilee in Leviticus 25: A Theological Ethical Interpretation from a South African Perspective, Lit Verlag, Münster.

Milgrom, J., 1991, Leviticus 1-16. A New Translation with Introduction and Commentary, Doubleday, New York.

Milgrom, J., 1999, 'The Antiquity of the Priestly Source: A Reply to Joseph Blenkinsopp', Zeitschrift für die Alttestamentliche Wissenschaft 111, 10-22.

Milgrom, J., 2000, Leviticus 17-22. A New Translation with Introduction and Commentary, Doubleday, New York.

Milgrom, J., 2001, Leviticus 23-27. A New Translation with Introduction and Commentary, Doubleday, New York.

Nicholson, E., 1998, The Pentateuch in the Twentieth Century. The Legacy of Julius Wellhausen. Oxford University Press, Oxford.

Otto, E., 1999, 'Innerbiblische Exegese im Heiligkeitsgesetz Levitikus 17-26' [Inner Biblical exegesis in the Holiness Code of Leviticus 17-26], in H.-J. Fabry \& H.-W. Jüngling (eds.), Levitikus als Buch, pp. 125-196, Philo, Bodenheim.

Ska, J-L., 2006, Introduction to Reading the Pentateuch, Eisenbrauns, Winona Lake.

Smith-Christopher, D.L., 2002, A Biblical Theology of Exile. Fortress Press, Minneapolis. 
Sperling, S.D., 2003, 'Pants, Persians and the Priestly Source', in R. Chazan, W.W. Hallo \& L.H. Schiffman (eds.), Ki Baruch Hu. Ancient Near Eastern, Biblical, and Judaic Studies in Honor of Baruch A. Levine, pp. 373-385, Eisenbrauns, Winona Lake.

Steymans, H.U., 1999, 'Verheißung und Drohung' [Promise and threat], in H.-J. Fabry \& H.-W. Jüngling (eds.), Levitikus als Buch, pp. 263-307, Philo, Bodenheim.
Zenger, E., 2004a, 'Theorien über die Entstehung des Pentateuch im Wandel der Forschung' [Theories about the origin of the Pentateuch in the course of research], in E. Zenger (ed.), Einleitung in das Alte Testament. 5. Auflage, pp. 74-123, Kohlhammer, Stuttgart.

Zenger, E., 2004b, 'Das priester(schrift)liche Werk (P)' [The Priestly sourcel, in E. Zenger (ed.), Einleitung in das Alte Testament. 5. Auflage, pp. 156-175, Kohlhammer, Stuttgart. 